\title{
Comparing Biochemical Profile of Admitted Patients with the Various Groups of Hyperglycemic Emergencies
}

\author{
Ezeani I.U. ${ }^{1,}$ Eregie A. ${ }^{2}$, Ogedengbe O.S ${ }^{2}$ \\ ${ }^{1}$ Department of Medicine,Federal Medical Center, UmuahiaAbia state, Nigeria. \\ ${ }^{2}$ Department of Medicine, University of Benin Teaching Hospital, Benin City, Nigeria.
}

\begin{abstract}
Objective: the objective of this study is to compare the biochemical profile in patients with hyperglycemic emergencies and to ascertain the factors associated with outcome with emphasis on the determinants of outcome.

Method: A total of 105 patients admitted to the Accident and Emergency unit who fulfilled the criteria for hyperglycaemic emergencies were selected using a non-probability sampling technique. The information extracted included socio-demographic, clinical and laboratory data and hospitalization outcome. Statistical comparison of proportions was done with chi-squared test, while the students $t$-test was used for comparison of means. A p-value of less than or equal to 0.05 was accepted as the level of statistical significance.

Results: Hyperosmolar hyperglycaemic non ketotic state (HHNK) was seen in 50\% (53) of the subjects, while diabetic ketoacidosis (DKA) was seen in 31\% (29), Normo osmolar non-ketotic hyperglycaemic state (NNHS) in $12 \%$ (13) and MIXED hyperglycaemic emergency in 7\% (10) of the subjects. There was a statistically significant difference in the mean RBS $(p=0.01)$, anion gap $(p=0.01)$, and in the mean serum osmolality $(p=0.01)$ however there was no statistically significant difference in the FBS on discharge $(p=0.14)$. Patients with Mixed hyperglycaemic emergency had the highest mean HbAlc (9.0 $\pm 0.47 \%)$ while patients with NNHS had the lowest mean HbAlc $(7.9 \pm 0.44 \%)$. Patients with HHNK had the highest mean admitting RBS $(611.4 \pm 68.11 \mathrm{mg} / \mathrm{dl})$ while patients with DKA had the lowest mean admitting RBS $(439.8 \pm 98.29 \mathrm{mg} / \mathrm{dl})$. The mean $(S D)$ serum potassium at presentation was $3.95 \mathrm{mmol} / \mathrm{L}(0.64)$ with a range of $2.2 \mathrm{mmol} / \mathrm{L}$ to $5.7 \mathrm{mmol} / \mathrm{L}$ : The mean $(S D)$ serum bicarbonate in this study was $19.3 \mathrm{mmol} / \mathrm{L}(2.87)$ with a range of 10 to $30 \mathrm{mmol} / \mathrm{L}$.

Conclusion:In view of the morbidity and mortality associated with hyperglycemic emergencies, there is need for prompt recognition and diagnosis and this highlights the need for provision of adequate diagnostic facilities in healthcare centers. Concerted efforts should be made by attending physicians in using biochemical parameters to make diagnosis of these hyperglycemic emergencies with a view to instituting prompt and adequate treatment.
\end{abstract}

Keywords: Diabetes mellitus, electrolytes, hyperglycemic emergencies, Insulin, ketones.

\section{Introduction:}

Hyperglycaemic emergencies (HE) are common acute complications of DM; e.g. diabetic ketoacidosis (DKA) and Hyperglycaemic Hyperosmolar Non-ketotic State (HHNK). These disorders are associated with absolute or relative insulin deficiency, volume depletion and acid-base abnormalities ${ }^{1}$. Both disorders are associated with potentially serious complications if not promptly diagnosed and treated, and successful treatment requires prompt and careful search for the precipitating causes ${ }^{2}$. Although HHNK and DKA have been described as distinct entities, one third of patients exhibit findings of both conditions ${ }^{3}$.

Although the pathogenesis of DKA is better understood than that of HHNK, the basic underlying mechanisms for both disorders include a reduction in the net effective action of insulin, coupled with a concomitant elevation of counterregulatory hormones such as glucagon, catecholamines, cortisol, and growth hormone ${ }^{4,5}$. Basically, HE results from relative or absolute insulin deficiency combined with counterregulatory hormone excess. The decreased ratio of insulin to glucagon promotes gluconeogenesis, glycogenolysis and ketone body formation in the liver as well as increase in substrate delivery from fat and muscle (free fatty acids, amino acids) to the liver ${ }^{1}$.

The initial laboratory evaluation includes determination of plasma glucose, blood urea nitrogen, creatinine, serum ketones, electrolytes (with calculated anion gap), osmolality, urinalysis, urine ketones by dipstick, as well as initial arterial blood gases and complete blood count with differentials ${ }^{6}$. An electrocardiogram, chest x-ray and urine, sputum or blood cultures should also be obtained, if clinically indicated ${ }^{6} . \mathrm{HbA}_{\mathrm{lc}}$ may be useful in determining whether this acute episode is the culmination of an evolutionary process in previously undiagnosed or poorly controlled diabetes or a truly acute episode in an otherwise well controlled patient ${ }^{6}$.Diabetic ketoacidosis is characterized by hyperglycaemia, ketosis and metabolic acidosis (increased anion gap) ${ }^{1}$. The anion gap is calculated by subtracting the sum of chloride and bicarbonate concentration from the sum of sodium and potassium concentration: 


$$
\left[\mathrm{Na}^{+}+\mathrm{K}^{+}-\left(\mathrm{Cl}^{-}+\mathrm{HCO}_{3}^{-}\right)\right]
$$

The normal anion gap has been historically reported to be $12 \pm 2 \mathrm{mEq} / \mathrm{l}^{7,8}$. Occasionally the serum glucose is only minimally elevated. Serum bicarbonate is frequently $<10 \mathrm{mmol} / 1$ and arterial $\mathrm{pH}$ ranges between 6.8 and 7.3 depending on the severity of the acidosis. Serum potassium at presentation may be elevated because of an extracellular shift of potassium caused by insulin deficiency, acidosis and hypertonicity ${ }^{6}$.

Patients with low normal or low serum potassium concentration on admission have severe fatal body potassium deficiency, require very careful cardiac monitoring and more vigorous potassium replacement because treatment lowers potassium further and can provoke cardiac dysrrhythmia ${ }^{1}$. Total body stores of sodium, chloride, phosphate and magnesium are also reduced in DKA but are not necessarily reflected by their levels in the serum because of dehydration and hyperglycemia. Amylase levels are elevated in the majority of patients with DKA, but this may be due to non pancreatic sources, such as the parotid gland ${ }^{6}$.

The laboratory features in HHNK include marked hyperglycaemia (plasma glucose may be $>55.5 \mathrm{mmol} / \mathrm{L}$ or $1000 \mathrm{mg} / \mathrm{dl})$, hyperosmolarity $(>350 \mathrm{mmol} / \mathrm{L})$, and pre-renal azotemia. In contrast to DKA, acidosis and ketonemia are absent or mild. A small anion gap metabolic acidosis may be present secondary to increased lactic acid. Moderate ketonuria if present may be secondary to starvation ${ }^{24}$. The majority of patients with hyperglycaemic emergencies present with leucocytosis proportional to blood ketone body concentration ${ }^{9,10}$. However leucocytosis $>25000$ cells $/ \mathrm{cm}^{3}$ may indicate infection and require further evaluation ${ }^{10}$.

\section{Method:}

This study was carried out in the Accident and Emergency unit, and the Medical wards of the University of Benin Teaching Hospital (UBTH), Benin City, Nigeria. Subjects recruited for this study were patients admitted at the Accident and Emergency unit of the University of Benin Teaching Hospital on account of a HE. Based on a calculated minimum sample size of 102, one hundred and five patients were recruited. The study was a prospective, longitudinal, study. Patients admitted to the Emergency unit who fulfilled the criteria for hyperglycaemic emergencies were selected using a non-probability sampling technique. The information that was extracted included socio-demographic, clinical and laboratory data. Subjects were recruited if: random plasma glucose $(\mathrm{RBS})>17 \mathrm{mmol} / 1(300 \mathrm{mg} / \mathrm{dl})$, ketonuria of $2+$ or more and serum bicarbonate of less than $18 \mathrm{mmol} / 1$ for $\mathrm{DKA}^{11,12}$; RBS > 25mmol/1 $(450 \mathrm{mg} / \mathrm{dl})$ and plasma osmolality $>320 \mathrm{mosmol} / 1$ with insignificant ketonuria for $\mathrm{HHNK}^{11,13}$; RBS > 17mmol/1 (300mg/dl), serum osmolality < 320mosmol/l and absent or minimal (1+) ketonuria for NNHS ${ }^{11,13}$; Mixed DKA and HHNK is based on RBS level $>300 \mathrm{mg} / \mathrm{dl}$, serum bicarbonate level $<15 \mathrm{mmol} / \mathrm{l}$ and ketonuria of $2+$ or more ${ }^{14,15}$; consenting patients (after verbal consent was obtained from them in the best understood language of the patient/relatives); patients aged above 18 years. The exclusion criteria included: patients diagnosed with end stage renal disease (ESRD), congestive cardiac failure (CCF), hepatic failure and anasarca due to their fluid overload since these conditions affect rapid intravenous fluid administration, patients with dementia in which there is alteration of mental state and likely inability to complain of hyperglycemic symptoms, pregnant women due to the gravid state. Ethical approval was obtained from the Ethics and Research committee of the University of Benin Teaching Hospital before the commencement of the study.

2.1 Treatment: Once the diagnosis was confirmed, therapy was commenced: Intravenous fluids and electrolyte replacement were given using isotonic saline and subsequently 5\% dextrose saline when blood sugar was less than $250 \mathrm{mg} / \mathrm{dl}$ or $13.8 \mathrm{mmol} / 1$.

A total of 20 units of soluble insulin (10units intravenously and 10units intramuscularly both as statim doses) was given and this was subsequently followed by 6units intravenously every hour until blood glucose levels fell to less than $250 \mathrm{mg} / 1$ (13.8mmol/l). Then 6units was added to each $500 \mathrm{mls}$ of dextrose saline infusion to run 4 hourly giving an insulin infusion rate of 0.025 units/minute.

Potassium replacement was instituted when the patient was making at least $30 \mathrm{mls} / \mathrm{hr}$ of urine and was not hyperkalemic. If serum potassium was less than $3.5 \mathrm{mmol} / 1,40 \mathrm{mmol}$ of potassium chloride $(\mathrm{KCl})$ was added to each litre of $5 \%$ dextrose saline. When serum potassium was between 3.5-5.5 mmol/1, 20mmol $\mathrm{KCl}$ was added and when more than $5.5 \mathrm{mmol} / \mathrm{l}, \mathrm{KCl}$ was withheld. Careful search for the event that precipitated the episode of HE was done if it was not obvious during initial history and physical examination (e.g. blood film for malaria parasite, urine and blood cultures, wound swab for microscopy, culture and sensitivity, chest x-ray, electrocardiogram).

Prophylactic low molecular weight heparin was instituted to prevent the occurrence of thromboembolism. Patients confused or unable to make urine or with impaired mental status had bladder catheterization done under sterile conditions using Foley's catheter. Urine collected was used for urine analysis, urine output estimation and also sent to the laboratory for microscopy, culture and sensitivity. 
2.2 Monitoring: This was done by finger prick every one hour for capillary blood using a glucose meter. Venous blood was taken at the $0,6,12$ and $24^{\text {th }}$ hour concurrently to compare with capillary glucose level and the results were charted. Blood urea and electrolytes were checked at 0,12 and 24 hours. The intravenous infusion was changed from normal saline to $5 \%$ dextrose saline once the blood glucose level was less than $13.8 \mathrm{mmol} / 1(250 \mathrm{mg} / \mathrm{dl})$ with 6 units of soluble insulin added to each infusion to run 4 hourly.

2.3 Bedside diagnosis of hyperglycaemic emergency: Capillary blood was obtained under strict sterile conditions for measurement of blood glucose level using Accu-check ${ }^{\circledR}$ glucose meter. Urine samples were also collected in universal bottles for estimation of protein, glucose, $\mathrm{pH}$, nitrite, leucocytes, and specific gravity using the dipstick. Unconscious patients were catheterized to obtain urine samples for analysis. Patient's urine output was also monitored concomitantly with input.

2.4 Collection of blood samples: At presentation, a peripheral fore-arm vein was cannulated under sterile conditions and a blood sample was collected for estimation of plasma glucose, urea, electrolytes, creatinine, packed cell volume and white blood cell count. Plasma separation was done after a 10minute centrifugation at a rate of 5000 revolutions per minute. The plasma was then stored in a freezer at $-4^{\circ} \mathrm{C}$ until analysis.

\subsection{Laboratory analysis:}

2.5.1 Calculated osmolality $(\operatorname{mosm} / \mathrm{l})$ :Serum osmolality was calculated as follows ${ }^{16 .}$

Osmolality $=2\left(\mathrm{Na}^{+}+\mathrm{K}^{+}\right)+$Glucose $(\mathrm{mmol} / \mathrm{l})+$ Urea $(\mathrm{mmol} / \mathrm{l})$ Normal range $=290-320 \mathrm{mosm} / 1$.

2.5.2 Calculated anion gap: Anion gap was calculated from sodium (Na) Potassium $(\mathrm{K}+)$, chloride $(\mathrm{Cl})$ and bicarbonate $\left(\mathrm{HCO}_{3}\right)$ in $\mathrm{mmol} / \mathrm{l}$ as follows ${ }^{16}$ :

Anion gap $=(\mathrm{Na}+\mathrm{K})-\left(\mathrm{Cl}+\mathrm{HCO}_{3}\right)$

Normal range $=10-18 \mathrm{mmol} / 1$.

2.5.3 Plasma glucose assay:_Plasma glucose levels were estimated according to Trinder's method using glucose oxidase solution ${ }^{18}$. The glucose oxidase was buffered in phenoxylate and dissolved in Sorenson buffer (colour reagent).

2.5.4 Capillary blood glucose: Capillary blood glucose was determined by the glucose dye oxido-reductase mediator reaction using Accu-chek Active ${ }^{\circledR}$ test strips and meter.

Each strip contains the following (minimum content per $\mathrm{cm}^{2}$ )

a) Bis(2-hydroxyethyl)-4(hydroximinocyclohexa-2,5-dienylidene) ammonium chloride 8.3pg.

b) Glucose dye oxido-reductase $0.7 \mathrm{u}$.

c) 2,18-Phosphomolybdic acid $88 \mu \mathrm{g}$.

d) Stabilizers $0.18 \mathrm{mg}$.

2.5.5 Electrolytes: Estimation of electrolytes was by ion selective electrode method (ISE), sodium potassium and chloride concentrations were determined by measuring potentials developed at the face of ion-selective membrane.

2.5.6 Packed cell volume: Venous blood was drawn into a heparinized glass capillary tube. Each was filled to about two-third of its length with blood. Plasticine was used to seal one end of the capillary tube. The tube was then placed in a centrifuge and spun at 5000rpm for 5 mins using a reader. The hematocrit was then determined.

\section{Results:}

3.1 Socio-demographic characteristics: Of the 105 subjects that completed the study, $53(51 \%)$ persons were male while 52 (49\%) persons were females. Ninety-one subjects (86.7\%) had type 2 DM and $14(13.3 \%)$ had type 1 DM. Of the 52 females studied, $47(90.4 \%)$ had type 2 DM while $5(9.6 \%)$ had type 1 DM. On the other hand, of the 53 male subjects that participated in the study, 44 (83\%) had type 2 DM while $9(17 \%)$ of them had type 1 DM. Twenty-eight (27\%) patients has had DM for more than or equal to 10 years duration while 77 (73\%) of the patients has had DM for less than 10years duration. Figure 1 below show a chart of distribution of subjects according to the type of diabetes mellitus. 
Figure 1. distribution of subjects according to the type of diabetes.

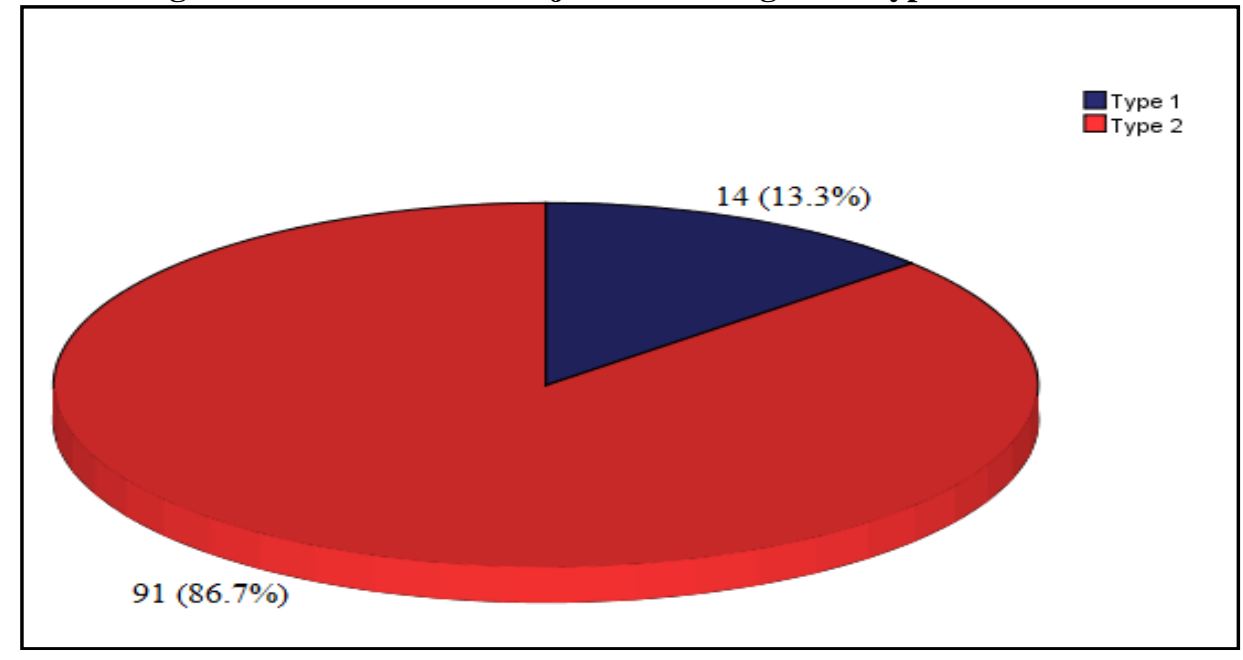

Table1: Comparison of means of biochemical parameters of subjects with hyperglycaemic emergencies using analysis of variance.

\begin{tabular}{|c|c|c|c|c|c|c|c|}
\hline PARAMETER & $\begin{array}{c}\text { DKA } \\
n=29 \\
\text { MEAN } \pm \text { SD }\end{array}$ & $\begin{array}{c}\text { HHNK } \\
n=53 \\
\text { MEAN } \pm \text { SD }\end{array}$ & $\begin{array}{c}\text { NNHS } \\
n=13 \\
\text { MEAN } \pm \text { SD }\end{array}$ & $\begin{array}{c}\text { MIXED } \\
n=10 \\
\text { MEAN } \pm \text { SD }\end{array}$ & $\mathbf{F}$ & df & $\mathbf{P}$ \\
\hline HbA1c (\%) & $8.5 \pm 0.28$ & $8.1 \pm 0.16$ & $7.9 \pm 0.44$ & $9.0 \pm 0.47$ & 1.78 & 3 & 0.16 \\
\hline $\begin{array}{l}\text { RBS ON ADMISSION } \\
(\mathrm{mg} / \mathrm{dl})\end{array}$ & $439.8 \pm 98.29$ & $611.4 \pm 68.11$ & $505.1 \pm 116.72$ & $596.8 \pm 67.72$ & 28.18 & 3 & 0.01 \\
\hline ANION GAP (mmol/L) & $24.2 \pm 3.91$ & $14.7 \pm 1.56$ & $14.1 \pm 2.11$ & $25.3 \pm 6.29$ & 83.93 & 3 & 0.01 \\
\hline $\begin{array}{l}\text { SERUM OSMOLALITY } \\
(\mathrm{mOsmol} / \mathrm{L})\end{array}$ & $303.9 \pm 75.91$ & $335.8 \pm 97.44$ & $312.6 \pm 51.42$ & $331.1 \pm 81.44$ & 96.04 & 3 & 0.01 \\
\hline $\begin{array}{l}\text { FBS ON DISCHARGE } \\
(\mathrm{mg} / \mathrm{dl})\end{array}$ & $102.9 \pm 12.77$ & $109.0 \pm 11.63$ & $104.2 \pm 12.02$ & $106.1 \pm 9.00$ & 1.86 & 3 & 0.14 \\
\hline
\end{tabular}

HbA1c= Glycosylated hemoglobin, RBS= Random blood sugar, FBS $=$ Fasting blood sugar, DKA= Diabetic ketoacidosis, HHNK= Hyperosmolar hyperglycemic non ketotic state, NNHS=Normo osmolar non ketotic hyperglycemic state, Mixed DKA/HHNK= Mixed diabetic ketoacidosis hyperglycemic hyperosmolar non ketotic state, $\mathrm{df}=$ degree of freedom, $\mathrm{SD}=$ standard deviation.

A comparison of means of biochemical parameters of subjects with the various hyperglycaemic emergencies shows a statistically significant difference in the mean RBS $(\mathrm{p}=0.01)$ and anion gap $(\mathrm{p}=0.01)$. Also, there is a statistically significant difference in the mean serum osmolality. Furthermore, there was no statistically significant difference in the FBS on discharge ( $\mathrm{p}=0.14)$. Patients with Mixed hyperglycaemic emergency had the highest mean HbA1c $(9.0 \pm 0.47 \%)$ while patients with NNHS had the lowest mean HbA1c $(7.9 \pm 0.44 \%)$. Patients with HHNK had the highest mean admitting RBS $(611.4 \pm 68.11 \mathrm{mg} / \mathrm{dl})$ while patients with DKA had the lowest mean admitting RBS $(439.8 \pm 98.29 \mathrm{mg} / \mathrm{dl})$. The mean anion gap was highest in patients with Mixed hyperglycaemic emergency $(25.3 \pm 6.29 \mathrm{mmol} / \mathrm{l})$, while patients with NNHS had the lowest mean anion gap $(14.1 \pm 2.11 \mathrm{mmol} / \mathrm{l})$. The mean serum osmolality was highest in patients with HHNK $(335.8 \pm 97.44 \mathrm{mOsmol} / \mathrm{l})$ while the lowest mean serum osmolality was documented in patients with DKA (303.9 $\pm 75.91 \mathrm{mOsmol} / \mathrm{l})$. Mean FBS on discharge was highest in patients with HHNK $(109.0 \pm 11.63 \mathrm{mg} / \mathrm{dl})$ while the lowest mean FBS on discharge was documented in patients with DKA $(102.9 \pm 12.77 \mathrm{mg} / \mathrm{dl})$. 
Table 2: Analysis of variance of electrolytes of subjects in the various hyperglycaemic groups.

\begin{tabular}{|c|c|c|c|c|c|c|c|}
\hline PARAMETER & $\begin{array}{l}\text { DKA } \\
n=29 \\
\text { MEAN } \pm \text { SD }\end{array}$ & $\begin{array}{l}\text { HHNK } \\
n=53 \\
\text { MEAN } \pm \text { SD }\end{array}$ & $\begin{array}{l}\text { NNHS } \\
n=13 \\
\text { MEAN } \pm \text { SD }\end{array}$ & $\begin{array}{l}\text { MIXED } \\
n=10 \\
\text { MEAN } \pm \text { SD }\end{array}$ & $\mathbf{F}$ & df & $\mathbf{P}$ \\
\hline $\mathrm{Na}^{+} \mathrm{mMol} / \mathrm{L}$ & $132.10 \pm 4.00$ & $143.28 \pm 3.85$ & $135.46 \pm 3.43$ & $136.60 \pm 3.50$ & 57.46 & 3 & 0.01 \\
\hline $\mathrm{K}^{+} \mathrm{mMol} / \mathrm{L}$ & $3.95 \pm 0.64$ & $4.07 \pm 0.74$ & $4.00 \pm 0.74$ & $3.49 \pm 0.83$ & 1.86 & 3 & 0.14 \\
\hline $\begin{array}{l}\mathrm{HCO}_{3}^{-} \mathrm{mMol} / \mathrm{L} \\
\mathrm{Cl}^{-} \mathrm{mMol} / \mathrm{L}\end{array}$ & $\begin{array}{l}13.83 \pm 1.83 \\
98.00 \pm 4.01\end{array}$ & $\begin{array}{l}23.72 \pm 2.57 \\
108.32 \pm 4.54\end{array}$ & $\begin{array}{l}20.38 \pm 3.57 \\
104.23 \pm 4.69\end{array}$ & $\begin{array}{l}13.00 \pm 1.70 \\
103.80 \pm 8.24\end{array}$ & $\begin{array}{l}126.15 \\
27.96\end{array}$ & $\begin{array}{l}3 \\
3\end{array}$ & $\begin{array}{l}0.01 \\
0.01\end{array}$ \\
\hline UREA $\mathrm{mMol} / \mathrm{L}$ & $44.90 \pm 30.81$ & $43.34 \pm 30.42$ & $33.46 \pm 12.80$ & $81.40 \pm 57.99$ & 4.72 & 3 & 0.01 \\
\hline $\begin{array}{l}\text { CREATININE } \\
\mathrm{mMol} / \mathrm{L}\end{array}$ & $1.25 \pm 0.52$ & $1.09 \pm 0.31$ & $0.89 \pm 0.22$ & $1.64 \pm 0.88$ & 6.30 & 3 & 0.01 \\
\hline
\end{tabular}

DKA=Diabetic ketoacidosis, $\mathrm{HHNK}=$ Hyperosmolar hyperglycaemic non-ketotic state, NNHS= Normo-osmolar non ketotic hyperglycaemic state, Mixed DKA/HHNK= Mixed Diabetic ketoacidosis/ Hyperosmolar hyperglycaemic non-ketotic state, df = degree of freedom, $\mathrm{p}=\mathrm{p}$-value, $\mathrm{SD}=$ standard deviation.

An analysis of variance of electrolytes of subjects in the various hyperglycaemic emergencies shows a statistically significant difference in the mean sodium $(\mathrm{p}=0.01)$, bicarbonate $(\mathrm{p}=0.01)$, chloride $(\mathrm{p}=0.01)$, urea $(\mathrm{p}=0.01)$ and creatinine $(p=0.01)$. However there was no statistically significant difference in the mean potassium $(p=0.14)$ among the various groups of hyperglycaemic emergencies.

Subjects with HHNK had the highest mean serum sodium $(143.28 \pm 3.85 \mathrm{mmol} / \mathrm{l})$ : this is followed by subjects with Mixed DKA/HHNK (136.60 $\pm 3.50 \mathrm{mmol} / \mathrm{l})$ and subjects with NNHS $(135.46 \pm 3.43 \mathrm{mmol} / \mathrm{l})$. The lowest mean serum sodium was seen in subjects with DKA $(132.10 \pm 4.0 \mathrm{mmol} / \mathrm{l})$.

Overall, the mean serum potassium was also highest in subjects with HHNK (4.07 \pm 0.74 mmol/l) followed by subjects in NNHS group of hyperglycaemic emergencies $(4.00 \pm 0.74 \mathrm{mmol} / \mathrm{l})$ and subjects with DKA $(3.93 \pm$ $0.64 \mathrm{mmol} / \mathrm{l})$. The Mixed DKA/NNHK group of hyperglycaemic emergencies had the lowest serum mean potassium levels.

The mean serum bicarbonate was lowest in subjects with Mixed DKA/HHNK $(13.00 \pm 1.70 \mathrm{mmol} / \mathrm{l})$ and subjects with DKA $(13.83 \pm 1.83 \mathrm{mmol} / \mathrm{l})$ : subjects with $\mathrm{HHNK}$ had the highest mean serum bicarbonate $(23.72 \pm 2.57$ $\mathrm{mmol} / \mathrm{l})$ and this is followed by subjects with NNHS $(20.38 \pm 3.57 \mathrm{mmol} / \mathrm{l})$. The mean serum chloride was highest in HHNK subjects $(108.32 \pm 4.54 \mathrm{mmol} / \mathrm{l})$ followed by NNHS subjects $(104.23 \pm 4.69 \mathrm{mmol} / \mathrm{l})$ and Mixed DKA/HHNK subjects $(103.80 \pm 8.24 \mathrm{mmol} / \mathrm{l})$ : it was lowest in subjects with DKA $(98.00 \pm 4.01 \mathrm{mmol} / \mathrm{l})$ when compared with the other hyperglycaemic emergencies.

Mean serum creatinine $(1.64 \pm 0.88 \mathrm{mg} / \mathrm{dl})$ and serum urea $(81.40 \pm 57.99 \mathrm{mg} / \mathrm{dl})$ were higher in subjects with mixed DKA/HHNK compared to the other groups of hyperglycaemic emergencies. On the other hand, subjects with NNHS had the lowest mean serum urea $(33.46 \pm 12.80 \mathrm{mg} / \mathrm{dl})$ and creatinine $(0.89 \pm 0.22 \mathrm{mg} / \mathrm{dl})$.

\section{Discussion:}

4.1 Pattern of hyperglycaemic emergencies: The categories of hyperglycaemic emergencies found in this study include DKA (Diabetic ketoacidosis), HHNK (Hyperosmolar hyperglycaemic non-ketotic), NNHS (Nonketotic Normo-osmolar hyperglycaemic state) and Mixed DKA/HHNK (Diabetic ketoacidosis/Hyperosmolar hyperglycaemic non-ketotic state). The most common hyperglycaemic emergency seen in this study was HHNK $(50 \%)$ and this finding was seen as expected, as it is commoner in type 2 diabetes which was the major type of DM seen in this study. The prevalence of DKA was $31 \%$, while NNHS was $12 \%$ and mixed DKA/HHNK was $7 \%$.

Patients with HHNK had the highest mean (SEM) age of 58.9 (1.69) years and this is similar to findings from other studies ${ }^{17,19,20}$. Diabetic ketoacidosis was found in $31 \%$ of patients and their mean (SEM) age was 43.4 (3.00) years. This finding is similar to the reports by Ehusani ${ }^{27}$, Ogbera et $\mathrm{al}^{21}$, Okoro et al ${ }^{20}$ and Adesina $^{22}$ who, in their various studies noted the occurrence of DKA in older subjects. Nine (33.3\%) of the patients with DKA were less than 30 years and this could be attributed the fact that majority of these persons had type $1 \mathrm{DM}$, which typically presents at a younger age (usually less than 30 years) ${ }^{11}$.

The prevalence of NNHS was $12 \%$ with a mean (SD) age of $58.1(14.32)$ years. This group of patients presented with hyperglycaemia in the presence of normo-osmolarity and absent or minimal acidosis. This is comparable with findings by Rolfe et $\mathrm{al}^{19}$ who also reported a prevalence of $19 \%$ in Johannesburg, South Africa. Ehusani ${ }^{17}$ and Adesina 22 reported a prevalence of $34.4 \%$ and $30 \%$ respectively in the same patient category. The possible explanation for this varied presentation is that hyperglycaemic emergencies exist as a spectrum and that NNHS exists at a point along this spectrum with HHNK supervening as osmotic diuresis worsens.

Mixed DKA/HHNK was found in 7\% of patients. The mean (SD) age of this group of patients was 57.2 (16.4) years. This is in keeping with findings from earlier studies by Ehusani ${ }^{17}$, Mac Isaac et $\mathrm{al}^{4}$, Wachtel et al ${ }^{6}$ and 
Adesina $^{22}$ who all reported a mixed picture of hyperglycaemic emergencies in a subset of persons in their various studies.

4.2 Plasma Glucose at presentation: The mean plasma glucose at presentation was $549 \mathrm{mg} / \mathrm{dl}$ (range of $304 \mathrm{mg} / \mathrm{dl}$ to $660 \mathrm{mg} / \mathrm{dl}$ ). The mean plasma glucose was highest in the HHNK group with a mean (SD) plasma glucose of 611.4 (68.11). Diabetic ketoacidosis had the lowest mean plasma glucose of $439.8 \mathrm{mg} / \mathrm{dl}$ (98.29). This finding is in keeping with the report of Ehusani ${ }^{17}$ and Rolfe et al ${ }^{19}$, who also reported the highest mean plasma glucose at presentation as being in the HHNK group.

Nineteen subjects $(18 \%)$ with hyperglycaemic emergency were presenting with diagnosis of DM for the first time. This finding is in keeping with the reports from the study done by Ehusani ${ }^{17}$, Ogbera et al ${ }^{21}$ and Adesina ${ }^{22}$ who reported prevalence rates (newly diagnosed DM) of $13.3 \%, 15 \%$ and $46 \%$ respectively. Another study done by Pepper et $\mathrm{al}^{23}$, in South Africa reported a prevalence of $11 \%{ }^{23}$. First presentation of DM as hyperglycaemic emergency is a recognized mode of presentation and possible reasons adduced to this includes ignorance of the symptoms of diabetes which ultimately leads to late presentation to the hospital.

\subsection{Serum electrolytes at presentation:}

4.3.1. Serum potassium:The mean (SD) serum potassium at presentation was $3.95 \mathrm{mmol} / \mathrm{L}(0.64)$ with a range of $2.2 \mathrm{mmol} / \mathrm{L}$ to $5.7 \mathrm{mmol} / \mathrm{L}$. This value is in keeping with findings from studies done by Ehusani ${ }^{17}$ who reported mean serum potassium of $4.6 \mathrm{mmol} / \mathrm{L}$ with a range of 3.2 to $6.0 \mathrm{mmol} / \mathrm{L}$; it is also in keeping with a previous report which showed that serum potassium levels at presentation may be varied (ranging from low, normal to mildly elevated) secondary to acidosis ${ }^{24}$.

Extracellular hyperosmolarity, secondary to hyperglycemia, causes a shift of water and potassium from the intracellular to the extracellular space, resulting in normal or elevated serum potassium concentrations despite total-body potassium deficits of $500-700 \mathrm{mEq} / \mathrm{l}^{5}$. This potassium shift is further enhanced by insulin deficiency and the presence of acidosis and accelerated breakdown of intracellular protein ${ }^{5}$. Hyperglycaemia leads to osmotic diuresis and renal loss of water and electrolytes ${ }^{5,25}$. Excessive urinary potassium losses, which occur as a result of osmotic diuresis with increased delivery of fluid and sodium to potassium secretory sites in the distal nephron, are ultimately responsible for the development of potassium depletion ${ }^{5,25}$. Secondary hyperaldosteronism and urinary ketoanion excretion, as potassium salts, further augment potassium losses ${ }^{5}$. During treatment of Hyperglycaemic emergencies with hydration and insulin, there is typically a rapid decline in plasma potassium concentration as potassium re-enters the intracellular compartment ${ }^{5}$.

Hypokalemia at presentation was noted in $9(9 \%)$ of subjects in this study and this is similar to the reports from the study by Adesina ${ }^{1}$ who noted hypokalemia in $8 \%$ of patients, while Ogbera et $\mathrm{al}^{21}$ in their study reported a higher prevalence of hypokalemia (37\%). Rajasoorya et $\mathrm{al}^{26}$ reported only two cases of hypokalemia in thirtythree DKA patients they studied while Beigelman ${ }^{25}$ in the United States reported hypokalemia in $4 \%$ of the DKA patients studied. Aurora et $\mathrm{al}^{27}$ reported that three $(5.6 \%)$ of the fifty-four subjects they studied had hypokalemia. The hypothesis that hypokalemia may predispose to mortality was further demonstrated by Talabi $^{28}$ in Ibadan who reported that $75 \%$ of the mortality they recorded occurred in subjects with hypokalemia. Hypokalaemia was not associated with mortality in this study.

Potassium replacement was instituted in this study once subjects had urine volume of at least $30 \mathrm{mls} / \mathrm{hr}$ and were not hyperkalemic. Other guidelines on approach to potassium replacement have been put forward. Potassium replacement at the onset of insulin administration has been advocated especially in developed countries where a facility for continual monitoring of potassium is available: $\mathrm{Oli}^{29}$ added potassium at the onset with the aim of preventing hypokalemia; however, he did not monitor serum electrolytes including serum potassium within the first eight hours of commencing treatment.

4.3.2. Serum bicarbonate:The mean (SD) serum bicarbonate in this study was $19.3 \mathrm{mmol} / \mathrm{L}(2.87)$ with a range of 10 to $30 \mathrm{mmol} / \mathrm{L}$. Rajasoorya et $\mathrm{al}^{26}$ in their study reported a mean serum bicarbonate level of $8.7 \mathrm{mmol} / \mathrm{L}$ with a range of 1.9 to $15 \mathrm{mmol} / \mathrm{l}(\mathrm{SD}=1.1)$ while Ehusani ${ }^{17}$ reported minimum bicarbonate level of $10 \mathrm{mmol} / \mathrm{L}$ which is similar to the finding from this study. Retrospective reviews have failed to identify changes in morbidity or mortality with sodium bicarbonate therapy ${ }^{30,31}$. After reviewing the risks and benefits of bicarbonate therapy, Mat $^{32}$ concluded that the only clear indication for use of bicarbonate is in cases of life-threatening hyperkalemia. Another study showed that ketoanion metabolism was delayed in the presence of bicarbonate therapy, but no significant difference in response between the bicarbonate and no bicarbonate groups was noted $^{33}$. A prospective randomized study examined the effect of bicarbonate versus no bicarbonate in two groups of DKA patients with similar degrees of acidemia ( $\mathrm{pH}$ 6.9-7.14) ${ }^{34}$. In some patients, initial cerebrospinal fluid (CSF) chemistry was measured and compared with initial plasma chemistry. It was of interest that $\mathrm{HCO}_{3}$ and $\mathrm{pH}$ in CSF were significantly higher than those in plasma of DKA patients. Conversely, ketones and glucose were higher in plasma than in CSF. However, CSF and plasma osmolalities were similar, indicating that the 
blood-brain barrier provided greater protection against acidosis for the brain ${ }^{34}$. Furthermore, regression analysis of the level of lactate, ketones, $\mathrm{pH}$, bicarbonate, and glucose showed no significant difference in the two groups with regard to slopes of these variables during recovery from DKA. It was therefore concluded that administration of bicarbonate in DKA patients (with $\mathrm{pH}$ of 6.9-7.14) provided no measurable advantage either biochemically or clinically ${ }^{34}$. Bicarbonate replacement is recommended if the serum bicarbonate level is less than $10 \mathrm{mmol} / \mathrm{l}$ or $\mathrm{pH}$ is less than $7^{35,36}$. However, no patient in this study had bicarbonate level less than $10 \mathrm{mmol} / \mathrm{l}$ and therefore, bicarbonate replacement was not instituted.

4.3.3. Serum sodium: the mean (SD) serum sodium in this study was $136.86 \mathrm{mmol} / \mathrm{l}$ (3.6) with a range of 132.1 to $143.28 \mathrm{mmol} / \mathrm{l}$. Subjects with HHNK had the highest mean serum sodium $(143.28 \pm 3.85 \mathrm{mmol} / \mathrm{l})$ : this is followed by subjects with Mixed DKA/HHNK (136.60 $\pm 3.50 \mathrm{mmol} / \mathrm{l})$ and subjects with NNHS $(135.46 \pm 3.43 \mathrm{mmol} / \mathrm{l})$. The lowest mean serum sodium was seen in subjects with DKA $(132.10 \pm 4.0$ $\mathrm{mmol} / \mathrm{l})$. Total body sodium in DKA is generally reduced but may not be accurately reflected in the serum as a result of dehydration and hyperglycemia (Harrison).

4.3.4. Serum chloride: The mean serum chloride was highest in HHNK subjects $(108.32 \pm 4.54 \mathrm{mmol} / \mathrm{l})$ followed by NNHS subjects $(104.23 \pm 4.69 \mathrm{mmol} / \mathrm{l})$ and Mixed DKA/HHNK subjects $(103.80 \pm 8.24 \mathrm{mmol} / \mathrm{l})$ : it was lowest in subjects with DKA $(98.00 \pm 4.01 \mathrm{mmol} / \mathrm{l})$ when compared with the other hyperglycaemic emergencies.Although studies comparing serum chloride levels in patients presenting with hyperglycemic emergencies are few, the high mean value in patients with HHNK is expected because of the hyperosmolarity associated with HHNK.

\section{Conclusion:}

Thisstudy provides an understanding of the biochemical profiles in patients admitted at our health facility with various types of hyperglycemic emergencies. The results from this study have shown that admitting blood glucose, serum osmolarity, electrolytes are highest in HHNK patients and lowest in patients with DKA. In other to reduce the morbidity and mortality in patients with hyperglycemic emergencies, diabetic counselling units should be established in hospitals manned by trained diabetic health counselors whose duties will include patient counselling on the symptoms of poor metabolic control and complications of diabetes. Furthermore, this study provides valuable findings regarding the pattern of HE presentation in our setting: apart from the common types like DKA and HHNK, other types not as common like NNHS and Mixed hyperglycemic emergencies were also reported lending credence to the need for healthcare providers to have a high index of suspicion in making diagnosis of HEs. In this regard, healthcare facilities should be equipped with appropriate laboratory equipment in addition to manpower training and development to enable close monitoring of biochemical indices especially electrolytes of patients with hyperglycaemic emergencies with a view to reducing morbidity and mortality

\section{References:}

[1]. Alvin CP. Diabetes Mellitus: Aetiological classification In: Kasper DL, Braunwald E, Fauci AS, Hauser SL, Longo DL, Jameson JL (eds). Harrison's principles of Internal Medicine. $16^{\text {th }}$ edition. Mc Graw Hill (Medical Publishing division) 2005: 323: 2153-2179.

[2]. Eregie A, Unadike BC. Common causes of morbidity and mortality amongst diabetic admissions at the University of Benin Teaching Hospital, Benin City, Nigeria. Pak J Med Res 2010; 49: 89-93.

[3]. Umpierrez GE, Murphy MB, Kitabchi AE. Diabetic Ketoacidosis and Hyperglycaemic Hyperosmolar Syndrome. Diabetes Spectrum 2002; 15: 28-36.

[4]. Mac Isaac RJ, Lee LY, Mc Neil KJ, Tsalamandris C, Jerums G. Influence of age on the presentation and outcome of acidotic and hyperosmolar diabetic emergencies. Internal Medicine Journal. 2002; 32: 379-385.

[5]. Kitabchi AE, Umpierrez GE, Murphy MB, Barret EJ, Kreisberg RA, Malone JI, Wall BM. Management of Hyperglycaemic crises in patients with diabetes. Diabetes Care. 2001; 24: 131-153.

[6]. Wachtel TJ, Tchi-Mouradjan LM, Goldman DL, Ellis SA, O’Sullivan PS. Hyperosmolarity and acidosis in diabetes morbidity. J Gen Int Met. 1991; 6: 495-502.

[7]. Lorber D. Non Ketotic hypertonicity in diabetes mellitus. Med Clin North Am.1995; 79: 39-52.

[8]. Winter SD, Pearson JR, Gabow PA, Schultz AL, Lepoff RB. The fall of the serum anion gap. Arch Intern Med .1990; 150: 311 313 .

[9]. Kitabchi AE, Guillermo E, Umpierre MD, Mary BM, Robert A, et al. Hyperglycaemic crises in Adult patients with Diabetes. Diabetes Care 2006; 29: 2739-2748.

[10]. Slovis CM, Mask VG, Slovis RJ, Bain RP. Diabetic Ketoacidosis and infection, leukocyte count and differential as early predictors of infection. Am J Emerg Med. 1987; 5: 1-5.

[11]. Brownlee M, Aiello LP, Cooper ME, Vinik AI, Nesto RW, Boulton AJM. Complications of Diabetes Mellitus In: Kronenberg HM et al (eds). Williams textbook of Endocrinology, $11^{\text {th }}$ Edition. Philadelphia: Saunders: an imprint of Elsevier Inc. 2008. 30-13291416.

[12]. Rheeder P. Type 2 diabetes: The emerging epidemic. South Afr Fam Pract. 2006; 48: 20.

[13]. Soderberg S, Zimmet P, Tuomilehto J, de Courten M, Dowse GK, Chitson P, et al. Increasing prevalence of type 2 diabetes melli tus in all ethnic groups in Mauritius. Diabet Med 2005; 22: 61-68.

[14]. Gharbi M, Aouidet A. Level of cardiovascular risk factors in the urban and rural populations of Cap-Bon: Tunisia. Rev Epidemiol Sante Publique 1996; 44: 125-32. 
[15]. Levitt NS. Diabetes in Africa: Epidemiology, management and healthcare challenges. Heart 2008; 94: 1376-1382.

[16]. Kumar P, Clark M. Water, electrolysis and acid-base balance. In: Clinical medicine $5^{\text {th }}$ edition. Elsevier Science Limited. 2002: 667-699.

[17]. Ehusani FO. Comparative study of intravenous insulin infusion and intermittent intramuscular injection of insulin in the management of hyperglycaemic emergencies. Part 2 FMCP dissertation, National Postgraduate Medical College (NPMC), 2000.

[18]. Trinder P. Determination of glucose in blood using glucose oxidase with an alternative oxygen acceptor. Ann Clin Biochem 1969; 6: $24-27$.

[19]. Rolfe M, Ephraim GG, Lincoln DC, Huddle KR. Hyperosmolar non ketotic diabetic coma as a cause of emergency Hyperglycaemic admission at Baragwaneth hospital. S Afr Med J.1995; 85: 173-176.

[20]. Okoro EO, Yusuf M, Salawu HO, Oyejola BA. Outcome of diabetic hyperglycaemic emergencies in a Nigerian cohort. Chinese Journal of Medicine 2007; 2. Accessed 28/9/07 http://www.ojmed.net/article.php.

[21]. Ogbera AO, Awobusuyi J, Unachukwu C, Fasanmade O. Clinical Features, predictive factors and outcome of hyperglycaemic emergencies in a developing country. BMC Endocr Disord. 2009; 9: 9.

[22]. Adesina OF. Comparison of Lispro insulin and regular insulin in the management of hyperglycaemic emergencies. Part 2 FMCP dissertation, National postgraduate Medical College (NPMC), 2008.

[23]. Pepper DJ, Levitt NS, Cleary S, Burch VC. Hyperglycaemic emergencies admissions to a secondary level hospital: an unnecessary financial burden. 2007. South Afr Med Journal. 97: 10: 963-967.

[24]. Alberti KGMM. Diabetic Acidosis, Hyperosmolar Coma and Lactic acidosis in: Becker KL(ed) principles and Practice of Endocrinology and Metabolism. $2^{\text {nd }}$ Edition. Philadelphia: J.B. Lippincott (Publishers) 1995: 1316-1327.

[25]. Beigelman PM. Potassium in severe Diabetic Ketoacidosis (Editorial): Am J Med. 1973: 54: 419-420.

[26]. Rajasoorya C, Wong SF, Chew LS. Diabetic ketoacidosis: a study of 33 episodes. Singapore Med J. 1993; 34 : 381-384.

[27]. Arora S, Cheng D, Wyler B, Menchine M. Prevalence of hypokalemia in ED patients with diabetic ketoacidosis. Am J Emerg Med. 2011 ;

[28]. Talabi OA. Is hypokalaemia the killer in diabetic hypoosmolar states during treatment? Diabetes International. $2000 ; 10: 2: 60-61$.

[29]. Oli JM. Biochemically unmonitored treatment of diabetic ketoacidosis for the first eight hours using the low dose intramuscular insulin regimen: preliminary report. Afr J Med Sci. 1979; 8: 1-5.

[30]. Anumah F, Ohwovoriole A. Serum biochemistry in Nigerians with hyperglycaemic emergencies. Ethnicity and Disease. PubMed.gov. 2008; 18(1): 26-30.

[31]. Lever E, Jaspan JB. Sodium bicarbonate therapy in severe diabetic ketoacidosis. Am J Med. 1983; 75: $263-268$.

[32]. Matz R. Diabetic acidosis: rationale for not using bicarbonate. N Y State J Med. 1977; 76: 1299-1303.

[33]. Hale PJ, Crase J, Nattrass M. Metabolic effects of bicarbonate in the treatment of diabetic ketoacidosis. Br Med Bull. 1984; 289: 1035-1038.

[34]. Morris LR, Murphy MB, Kitabchi AE. Bicarbonate therapy in severe diabetic ketoacidosis. Ann Intern Med. 1986; 105: 836-840.

[35]. Kitabchi AE, Wall BM. Diabetic ketoacidosis. Medical Clinics of North America. 1995; 78: 9-37.

[36]. Guerci B, Tubiana-Rufi N, Bauduceau B, Bresson R, Cuperlier A, Delcroix C et al. Advantages of using capillary blood betahydroxybutyrate determination for the detection and treatment of diabetic ketosis. Diabetes Metab. 2005; 31: 4: 401-406. 